\title{
MPP3 Gene
}

National Cancer Institute

\section{Source}

National Cancer Institute. MPP3 Gene. NCI Thesaurus. Code C24611.

This gene plays a role in cytoskeletal modeling, intercellular communication and cell proliferation. 